\title{
S-layer protein production by Corynebacterium strains is dependent on the carbon source
}

\author{
Emmanuelle Soual-Hoebeke, ${ }^{1}$ Célia de Sousa-D'Auria, ${ }^{1}$ Mohamed \\ Chami, ${ }^{3}$ Maire-France Baucher, ${ }^{1}$ Armel Guyonvarch, ${ }^{1}$ Nicolas Bayan, ${ }^{2}$ \\ Karima Salim ${ }^{4}$ and Gérard Leblon ${ }^{1}$
}

Author for correspondence: Gérard Leblon. Tel: +331691562 81. Fax: + 33169155712 . e-mail: leblon@igmors.u-psud.fr

\footnotetext{
1,2 Laboratoire de Biologie Moléculaire des Corynébactéries, Institut de Génétique et Microbiologie, UMR C8621 CNRS, Bât. 4091, and Laboratoire des Biomembranes, UMR 8619 CNRS, Bât. $430^{2}$ Université Paris XI, 91405 Orsay Cedex, France

3 Centre de Génétique Moléculaire, CNRS, 91190 Gif sur Yvette, France

4 ORSAN SA, 46 rue de Nesle, BP 42, 80190 Mesnil Saint Nicaise, France
}

\begin{abstract}
Three strains of Corynebacterium producing various amounts of PS2 S-layer protein were studied. For all strains, more PS2 was produced if the bacteria were grown in minimal medium supplemented with lactate than if they were grown in minimal medium supplemented with glucose. The consumption of substrate and PS2 production was studied in cultures with mixed carbon sources. It was found that the inhibitory effect of glucose consumption was stronger than the stimulatory effect of lactate in one strain, but not in the other two strains. The regulation of gene expression involved in S-layer formation may involve metabolic pathways, which probably differ between strains. S-layer organization was also studied by freeze-fracture electron microscopy. It was found that low levels of PS2 production correlated with the partial covering of the cell surface by a crystalline array. Finally, it was found that PS2 production was mainly regulated by changes in gene expression and that secretion was probably not a limiting step in PS2 accumulation.
\end{abstract}

Keywords: S-layer, freeze fracture, carbon regulation

\section{INTRODUCTION}

The 'surface layer' (S-layer) of many bacteria consists of a single (glyco)protein species that is assembled into a two-dimensional crystalline array enveloping the cell (Sleytr et al., 1996). Large amounts of the protein are produced $(10-15 \%$ of total cell protein) and in most cases the protein is the major protein species produced by the cell (Messner \& Sleytr, 1992). Genetic analyses have been used to investigate the mechanism and regulation of biosynthesis of the protein. The corresponding genes have been identified in many species (Boot \& Pouwels, 1996). It has been calculated that approximately $5 \times 10^{5}$ monomers are required to cover a rod-shaped bacterium of average size (Sleytr \& Messner, 1989). Thus, for a generation time of $20 \mathrm{~min}$ in a particular medium, a single gene must produce at least 500 protein molecules per second to cover the cell completely with the S-layer (Sleytr \& Messner, 1989). In some cases, an excess of protein is even produced (Sleytr \& Glauert, 1976; Lewis et al., 1987; Breitwieser et al., 1992). The high rate of S-layer protein synthesis is due to a high level of gene transcription and/or mRNA stability.

Very little is known about the regulation of S-layer protein synthesis. Multiple transcription initiation sites have been identified in the operon encoding cell-wall proteins in Bacillus brevis 47 (Adachi et al., 1989) and regulation of S-layer protein gene expression has also been observed (Adachi et al., 1991). The half-life of mRNA has been found to be long: $10-15 \mathrm{~min}$ in Caulobacter crescentus (Fisher et al., 1988), $22 \mathrm{~min}$ in Aeromonas salmonicida (Chu et al., 1993), $15 \mathrm{~min}$ in Lactobacillus acidophilus (Boot et al., 1996a) and $14 \mathrm{~min}$ in Lactobacillus brevis (Kahala et al., 1997). Changes in the S-layer protein have been described in Campylobacter fetus (Garcia et al., 1995; Dwokin \& Blaser 1996), Lactobacillus acidophilus ATCC 4356 (Boot et al., 1996b), Bacillus stearothermophilus (Sára \& Sleytr, 1994; Sára et al., 1996) and Thermus thermophilus HB8 (Olabarría et al., 1996). In T. thermophilus HB8, the Cterminal fragment of the S-layer SlpA protein binds to the $5^{\prime}$ untranslated leader region of the $s l p A$ mRNA, providing evidence for translational auto-regulation in S-layer gene expression (Fernández-Herrero et al., 1997).

In the amino-acid-producing bacterium Corynebacterium glutamicum, two major proteins, PS1 and PS2, with apparent molecular masses of 67 and $63 \mathrm{kDa}$ (Joliff et al., 1992) have been identified in the cell wall. Corynebacterium belongs to the actinomycete sub- 
division of the Gram-positive bacteria and has a high $\mathrm{G}+\mathrm{C}$ content (Liebl \& Sinskey, 1988). The gene encoding the PS2 protein $(\operatorname{csp} B)$ has been characterized in C. glutamicum (Peyret et al., 1993). Chami et al. (1995) showed that if C. glutamicum was grown on solid medium, the surface of cells was totally covered with a highly ordered, hexagonal surface layer, whereas if it was grown in liquid medium, the cell and fracture surfaces were only partially covered by ordered arrays. This partial covering was correlated with there being less PS2 associated with the cell wall. Typically, cells grown on solid medium contained 34 mg PS2 protein (g bacterial dry $\mathrm{wt})^{-1}$, whereas cells grown in liquid medium to stationary phase contained $16 \mathrm{mg}$ (g dry $w t)^{-1}$. This suggests that PS2 production depends on the physiological and metabolic state of the cell.

Here we report that the amount of S-layer PS2 protein present depends on the carbon source available in the growth medium. We also show that a low level of PS2 production is associated with partial covering of the cell surface by a crystalline array.

\section{METHODS}

Bacterial strains, plasmids and culture conditions. The following Escherichia coli strains were used : JM110 [ $\mathrm{F}^{\prime}$ traD36 lacl $^{\mathrm{q}} \Delta$ (lacZ)M15 pro $A^{+} B^{+} /$rpsL (Str ${ }^{\mathrm{r}}$ ) thr leu thi lacY galK galT ara fhuA dam dcm supE44 $\Delta$ (lac-proAB)] (YanischPerron et al., 1985), DH5 $\alpha \mathrm{F}^{\prime}\left[\mathrm{F}^{\prime} /\right.$ endA1 hsdR $17\left(\mathrm{r}_{\mathrm{k}}^{-} \mathrm{m}_{\mathrm{k}}^{+}\right)$supE44 thi-1 recA1 gyrA $\left(\mathrm{Nal}^{\mathrm{r}}\right)$ relA1 $\Delta($ laclZYA-argF $) \mathrm{U} 169$ deoR $\phi 80 \mathrm{~d} l a c \Delta$ (lacZ)M15] (Biolabs) and EB 106 (icd-11 dadR1 trpA62 trpE61 tna-5 $\lambda^{-}$) (Apostolakos et al., 1982). The Corynebacterium melassecola ATCC 17965 and Corynebacterium sp. 2262 strains were supplied by Orsan and are described by Mondain-Monval (1988) and by Debay (1997), respectively. As stated by Peyret et al. (1993), C. melassecola ATCC 17965 is also known as C. glutamicum strain C. melassecola. Corynebacterium sp. 2262 is permissive for transformation with plasmid DNA extracted from E. coli $\mathrm{DH} 5 \alpha \mathrm{F}^{\prime}$ and Corynebacterium glutamicum ATCC 14752 is permissive for transformation with plasmid DNA from the dam dcm E. coli JM110 strain. C. glutamicum ATCC 14752 was obtained from the American Type Culture Collection, Manassas, VA, USA.

pMF2 was derived from pMC1403 (Casadaban et al., 1980) as follows. The aphIII gene from Streptococcus faecalis (TrieuCuot \& Courvalin, 1983), isolated from pCGL243 (Reyes et al., 1991) as a XhoI/NotI cassette, and a NotI/XhoI fragment of the icd locus of C. melassecola ATCC 17965 were inserted together into the SalI site of pMC1403 to give pMF2. The icd gene encoding the isocitrate dehydrogenase of C. melassecola was cloned by heterologous complementation of the E. coli mutant EB 106 as described by Eikmanns et al. (1995). The chromosomal DNA library used for the isolation of the icd gene of C. melassecola was described by Reyes et al. (1991). The E. coli-Corynebacterium shuttle vectors pCGL482 and pCGL815 were described by Peyret et al. (1993).

Bacterial cells were cultured in MCGC minimal medium as described by Von der Osten et al. (1989), except that citrate (used as a chelating agent) was replaced by deferoxamine. This medium contained $\left(1^{-1}\right): 3 \mathrm{~g} \mathrm{Na}_{2} \mathrm{HPO}_{4}, 6 \mathrm{~g} \mathrm{K \textrm {K } _ { 2 }} \mathrm{PO}_{4}, 2 \mathrm{~g}$ $\mathrm{NaCl}, 8 \mathrm{~g}\left(\mathrm{NH}_{4}\right)_{2} \mathrm{SO}_{4}, 0.4 \mathrm{~g} \mathrm{MgSO}_{4} .7 \mathrm{H}_{2} \mathrm{O}, 40 \mathrm{mg} \mathrm{FeSO}_{4} .7$ (a)

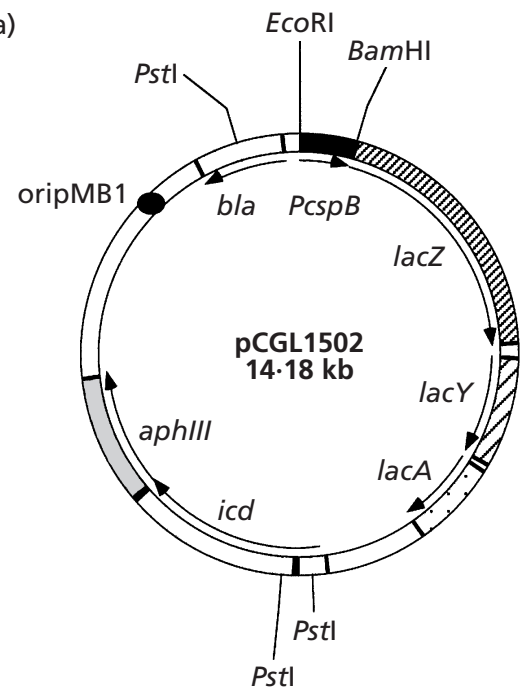

(b)

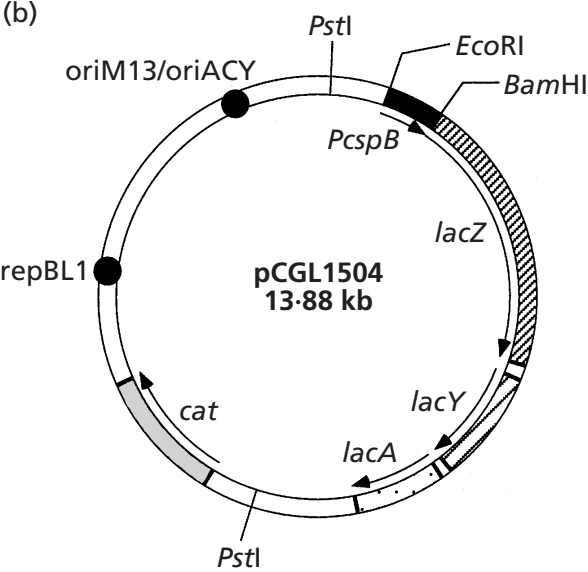

Fig. 1. Restriction maps of pCGL1502 and pCGL1504. The positions of the promoter region of the $\operatorname{csp} B$ gene and the orientations of transcription of lacZ, lacA, lacY, icd, aphIII, bla and cat are indicated. The positions of the origins of DNA replication (oripMB1, oriM13/oriACY, repBL1) are also indicated.

$\mathrm{H}_{2} \mathrm{O}, 3.9 \mathrm{mg} \mathrm{FeCl}, 0.9 \mathrm{mg} \mathrm{ZnSO}_{4} .7 \mathrm{H}_{2} \mathrm{O}, 0.3 \mathrm{mg} \mathrm{CuCl}{ }_{2} .2$ $\mathrm{H}_{2} \mathrm{O}, 3.9 \mathrm{mg} \mathrm{MnSO}_{4} . \mathrm{H}_{2} \mathrm{O}, 0 \cdot 1 \mathrm{mg}\left(\mathrm{NH}_{4}\right)_{6} \mathrm{Mo}_{7} \mathrm{O}_{24} \cdot 4 \mathrm{H}_{2} \mathrm{O}$, $0.3 \mathrm{mg} \mathrm{Na}{ }_{2} \mathrm{~B}_{4} \mathrm{O}_{7} .10 \mathrm{H}_{2} \mathrm{O}, 84 \mathrm{mg} \mathrm{CaCl}, 4 \mathrm{mg}$ biotin, $20 \mathrm{mg}$ thiamin and $3 \mathrm{mg}$ deferoxamine. The carbon sources were added to a final concentration of $180 \mathrm{mM}\left(30 \mathrm{~g} \mathrm{l}^{-1}\right.$ for glucose and $20 \mathrm{~g} \mathrm{l}^{-1}$ for lactate) or $90 \mathrm{mM}$ for single or mixed carbon source experiments, respectively. Corynebacterium cells were grown aerobically at $34^{\circ} \mathrm{C}$ with shaking (250 r.p.m.). Chloramphenicol $\left(\mathrm{Cm} ; 15 \mu \mathrm{g} \mathrm{ml}^{-1}\right)$ or kanamycin $\left(\mathrm{Km} ; 25 \mu \mathrm{g} \mathrm{ml}^{-1}\right)$ were added as required.

Construction of the $\mathbf{P} \operatorname{csp} \boldsymbol{B}^{\prime}-\mathbf{l a c Z}$ fusion. The $\operatorname{csp} B$ promoter $(P \operatorname{csp} B)$ described by Peyret et al. (1993) was isolated as a $554 \mathrm{bp} E c o \mathrm{RI} / E c o \mathrm{NI}$ fragment and ligated to an EcoNI/ BamHI adaptor constructed with the two synthetic oligonucleotides 5'-TCAAGGAGCCTTCGCCTCTATG-3' and 5'-GATCCATAGAGGCGAAGGCTCCTTG-3'. The resulting EcoRI/BamHI fragment was inserted between the EcoRI and BamHI sites of pMF2 to give pCGL1502 (Fig. 1a), in 
which the $c s p B$ and $l a c Z$ genes are fused at the Bam HI site. Thus, pCGL1502 carries an in-phase fusion between the first codon of $c s p B$ and lacZ. A $7.92 \mathrm{~kb}$ Pst I fragment from pCGL1502 containing the PcspB'-lacZ fusion was inserted into the single PstI site of the E. coli-Corynebacterium shuttle vector pCGL482 to give pCGL1504 (Fig. 1b).

DNA manipulations. Plasmid DNA was isolated from Corynebacterium strains by alkaline lysis (Birnboim \& Doly, 1979). Genomic DNA was extracted as described by Ausubel et al. (1987). Integration into the Corynebacterium chromosome was checked by Southern blotting with non-radioactively labelled DNA probes as described by Labarre et al. (1993). Restriction endonucleases and DNA-modifying enzymes were purchased from Promega. Corynebacterium strains were transformed by electroporation as described previously (Bonamy et al., 1990), with 100-200 ng plasmid DNA bearing either kanamycin (pCGL1502) or chloramphenicol (pCGL1504) resistance genes.

Extraction of PS2 protein and quantification of PS2 production. Proteins were extracted from the cell walls of Corynebacterium cultures with $2 \%(\mathrm{w} / \mathrm{v})$ SDS, as described by Peyret et al. (1993). A bacterial pellet was obtained from $2 \mathrm{ml}$ cell culture and suspended in $200 \mu \mathrm{l}$ Tris/ $\mathrm{HCl}$ buffer (50 mM, pH 6.8) containing $2 \%$ SDS. The suspension was heated to $100{ }^{\circ} \mathrm{C}$ for $5 \mathrm{~min}$ and centrifuged at $16000 \mathrm{~g}$ for 3 min. The supernatant containing the proteins associated with the cell wall (mainly PS2) was collected. This treatment does not solubilize the cytoplasmic membrane or result in cell lysis (Bayan et al., 1993). SDS-PAGE was carried out as described by Laemmli (1970), with a $4 \%$ acrylamide stacking gel and a $10 \%$ acrylamide separating gel. The volume of protein extract used was calculated so as to give samples with equivalent optical density at $570 \mathrm{~nm}$. The samples were denatured by heating at $100{ }^{\circ} \mathrm{C}$ for $5 \mathrm{~min}$ in the presence of $2 \%$ SDS and $1.25 \%(\mathrm{w} / \mathrm{v}) \beta$-mercaptoethanol in $50 \mathrm{mM}$ Tris/ $\mathrm{HCl} \mathrm{pH} 6.8$. The samples were then subjected to electrophoresis; under these conditions, PS2 protein had an apparent molecular mass of $63 \mathrm{kDa}$ (Joliff et al., 1992). After electrophoresis, the gels were stained with Coomassie brilliant blue R-250. PS2 protein was determined by densitometry (ImagQuant) and $1 \mu \mathrm{g} \beta$ galactosidase was loaded on the gel as a control for quantity. The amount of PS2 protein is expressed in $\mathrm{mg}$ protein ( $\mathrm{g}$ bacterial dry $\mathrm{wt})^{-1}$. Biomass $(\mathrm{Bm})$ was determined as a function of optical density at $570 \mathrm{~nm}$ using an $\alpha$ correlation factor for each Corynebacterium strain: $\mathrm{Bm}=\mathrm{OD}_{570} / \alpha$. To determine the $\alpha$ factor, $200 \mathrm{ml}$ bacterial cells were harvested from a culture in stationary phase with a known $\mathrm{OD}_{570}$ value by centrifugation for $20 \mathrm{~min}$ at $3500 \mathrm{~g}$. The pellet was dried at $60{ }^{\circ} \mathrm{C}$ for $15 \mathrm{~h}$ and its weight was determined. This procedure was carried out for three independent cultures. The $\alpha$ factor was calculated for all carbon sources tested.

Freeze-fracture electron microscopy. A bacterial suspension was placed between a thin copper holder and a thin copper plate and quenched in liquid propane, as described by GulikKrzywicki \& Costello (1978) and Aggerbeck \& GulikKrzywicki (1986). The frozen sample was fractured at $-125^{\circ} \mathrm{C}$ in vacuum of about $1.33 \times 10^{-5} \mathrm{~Pa}$ by removing the upper plate with a liquid-nitrogen-cooled knife in a Balzers 301 freeze-etching unit.

The fractured sample was etched at $-105^{\circ} \mathrm{C}$ for $3-5 \mathrm{~min}$ and a replica was produced with platinum-carbon or tungstentantalum (1.0-1.5 nm of metal deposited), backed with about $20 \mathrm{~nm}$ of carbon. The replica was cleaned by incubation overnight with chromic acid, washed with distilled water and observed in a Philips 410 electron microscope.
Glucose and lactate assays. For glucose and lactate determinations in culture media, bacterial cells $(2 \mathrm{ml})$ were centrifuged and the supernatant filtered through $0.45 \mu \mathrm{m}$ pore filters (Millipore). Samples were stored at $-20{ }^{\circ} \mathrm{C}$ until use. Extracellular glucose and lactate concentrations were determined with a sensitive colorimetric enzyme assay (Sigma Diagnostics glucose procedure no. 315 and Sigma Diagnostics lactate procedure no. 735, respectively). The kits for glucose and lactate assays were purchased from Sigma and used as recommended by the manufacturer.

$\boldsymbol{\beta}$-Galactosidase activity in cytoplasmic extracts. Bacterial cells $(20 \mathrm{ml}$ of stationary phase culture) were collected by centrifugation and resuspended in $2 \mathrm{ml}$ buffer A $(100 \mathrm{mM}$ Tris $/ \mathrm{HCl} \mathrm{pH} \mathrm{8,} 500 \mathrm{mM} \mathrm{KCl,} 1 \mathrm{mM} \mathrm{MgSO}_{4} .7 \mathrm{H}_{2} \mathrm{O}, 0 \cdot 4 \mathrm{mM}$ $\mathrm{MnSO}_{4}, 4 \mathrm{mM}$ DTT). The cell suspension was mixed with $1 \mathrm{~g}$ glass beads (106 $\mu \mathrm{m}$ diameter; Sigma), and was shaken for two periods of $5 \mathrm{~min}$, each at 1800 vibrations $\mathrm{min}^{-1}$ (Retsch MM 2000). The suspension was centrifuged at $20800 \mathrm{~g}$ and the supernatant was used as a cytoplasmic extract. $\beta$-Galactosidase activity was measured as follows. Cytoplasmic extract $(270 \mu \mathrm{l})$ was mixed with $180 \mu \mathrm{l}$ of a solution of $4 \mathrm{~g} \mathrm{ONPG}^{-1}$. The absorbance of the mixture at $420 \mathrm{~nm}\left(A_{420}\right)$ was monitored for $10 \mathrm{~min}$ at room temperature. The protein concentration of the extract was also determined by the Lowry method (DC protein assay, Bio-Rad). Specific $\beta$-galactosidase activity is expressed as $\left[\AA_{420} \min ^{-1}(\mu \mathrm{g} \text { protein })^{-1}\right] \times 1000$.

\section{RESULTS}

\section{PS2 production as a function of carbon source}

We assessed the PS2 protein production of three strains of Corynebacterium grown in liquid minimal medium (MCGC) supplemented with either glucose or lactate. PS2 production was assessed by densitometry (Fig. 2). The three strains produced different amounts of PS2.

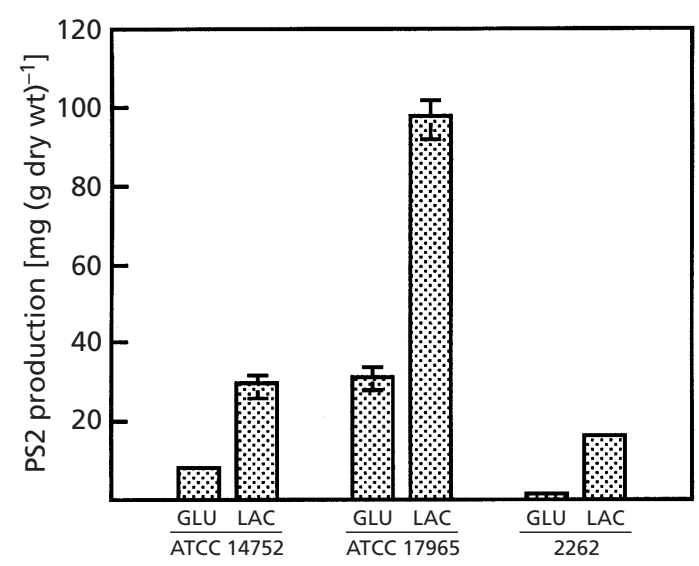

Fig. 2. Amount of PS2 protein produced by C. glutamicum ATCC 14752, C. melassecola ATCC 17965 and Corynebacterium sp. 2262. Cells were grown in MCGC minimal medium supplemented with either glucose (GLU) or lactate (LAC). Cell wall proteins were recovered from the pellet and the amount of PS2 quantified as described in Methods. The volume of protein extracts used was calculated such that it gave samples with equivalent optical density at $570 \mathrm{~nm}\left(\mathrm{OD}_{570}=12\right.$ for $C$. glutamicum ATCC 14752, 9 for C. melassecola ATCC 17965 and 10 for Corynebacterium sp. 2262). Results shown are means \pm SD of three independent determinations. 

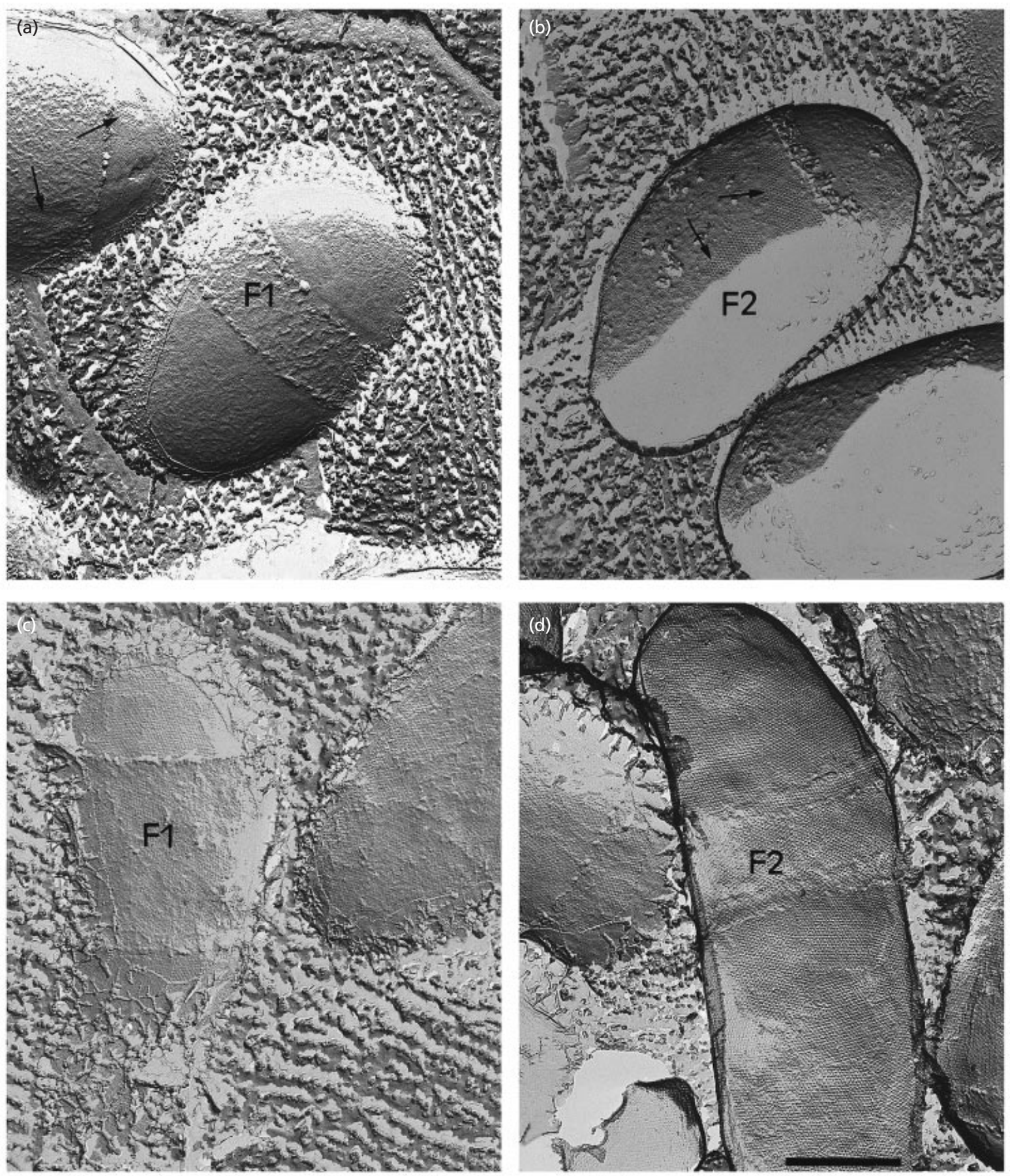

Fig. 3. Electron micrograph of a freeze-fracture and deep-etched preparation of C. glutamicum ATCC 14752 cells. F1, convex fracture surface; F2, concave fracture surface. Arrows indicate S-layer. (a, b) Cells grown on minimal medium supplemented with glucose. (c, d) Cells grown on minimal medium supplemented with lactate. Bar, $0.5 \mu \mathrm{m}$.

The largest amount of PS2 as a proportion of bacterial dry weight was detected if cells were grown in the presence of lactate: $30 \mathrm{mg}$ PS2 protein (g bacterial dry $\mathrm{wt})^{-1}$ for C. glutamicum ATCC 14752, $98 \mathrm{mg}$ (g dry $\mathrm{wt})^{-1}$ for C. melassecola ATCC 17965 and $15 \cdot 8 \mathrm{mg}$ (g dry wt $)^{-1}$ for Corynebacterium sp. 2262. The amount of
PS2 produced in the presence of lactate was 4-fold higher than that in the presence of glucose for C. glutamicum ATCC 14752, 3-fold higher for C. melassecola ATCC 17965 and 13-fold higher for Corynebacterium sp. 2262. This suggests that lactate consumption increased PS2 production. 

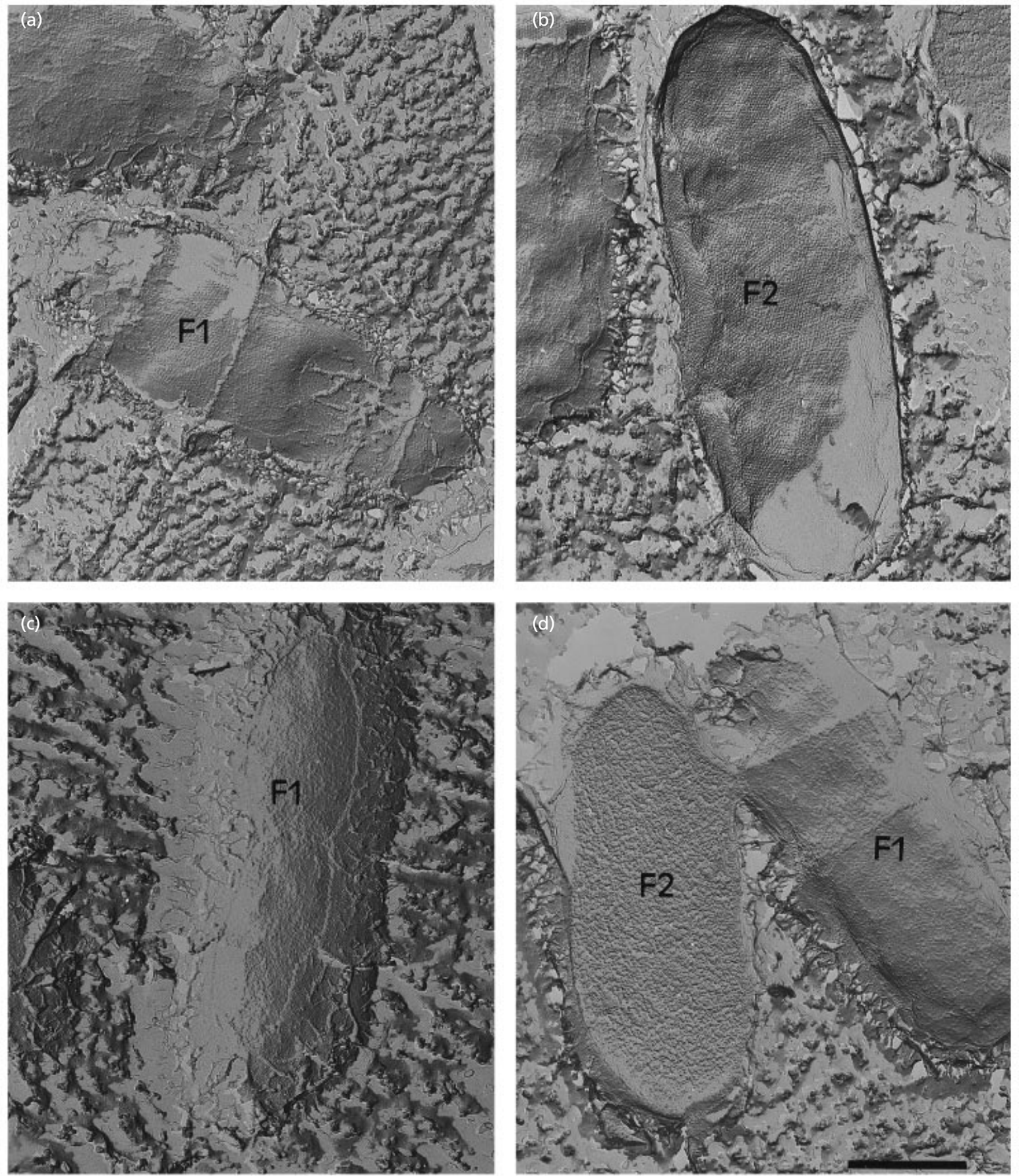

Fig. 4. Electron micrograph of a freeze-fracture and deep-etched preparation of C. melassecola ATCC 17965 cells. F1, convex fracture surface; F2, concave fracture surface. $(a, b)$ Cells grown on minimal medium supplemented with glucose. (c, d) Cells grown on minimal medium supplemented with lactate. Bar, $0.5 \mu \mathrm{m}$.

\section{S-layer formation as a function of growth on glucose or lactate}

As PS2 production was highly dependent upon the carbon source, we investigated whether carbon source also affected S-layer formation. We carried out freezefracture electron microscopy with all three strains grown on either glucose or lactate. This technique is suitable for the observation of the S-layer in Corynebacterium because the main fracture plane is propagated between the S-layer and the cell wall and produces two fracture surfaces: F1, the convex fracture surface, and F2, the concave fracture surface. The S-layer can be observed on the concave fracture surface (F2) and its imprint can be 

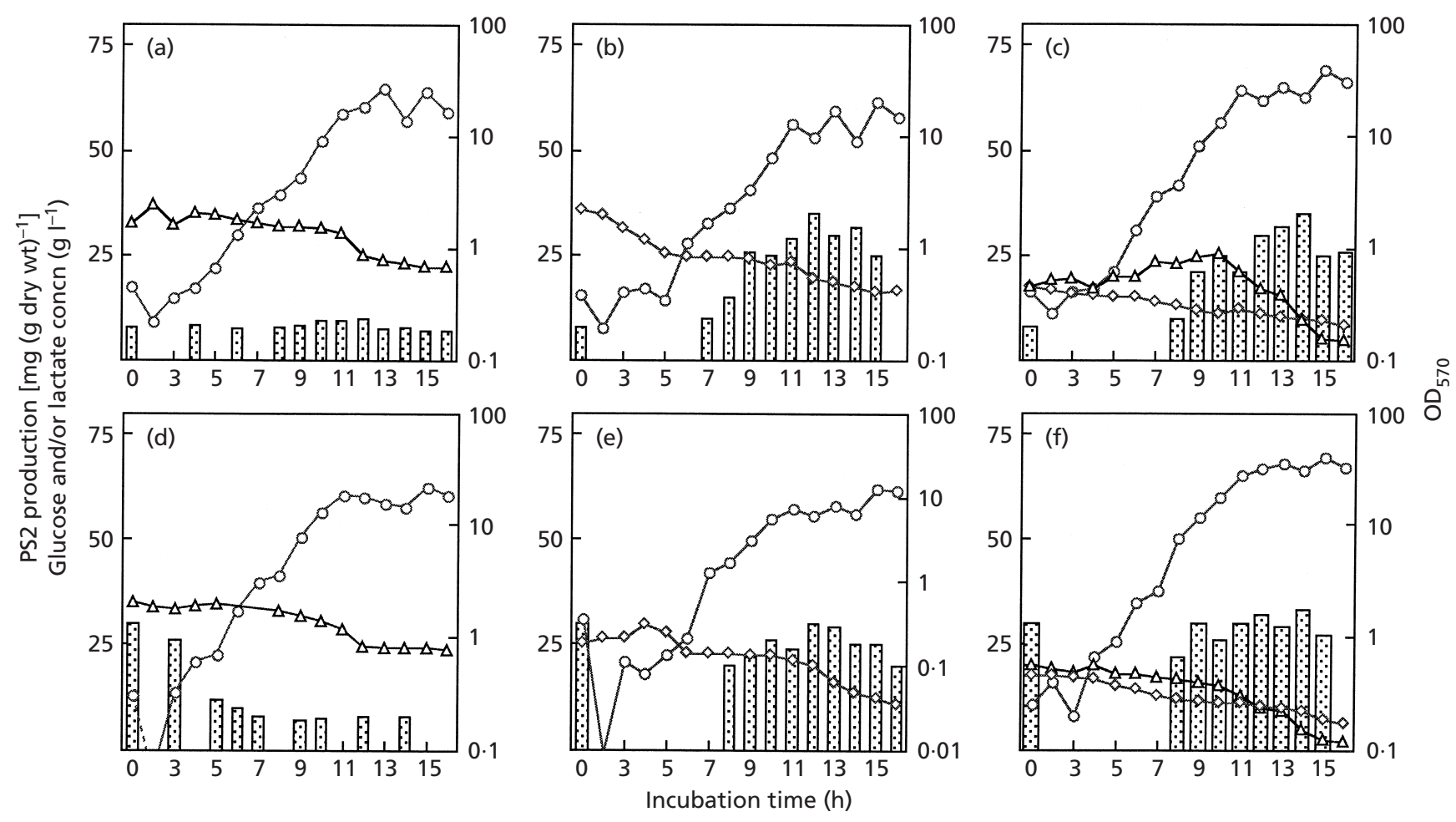

Fig. 5. Relationship between the consumption of various carbon sources and PS2 protein production by $C$. glutamicum ATCC 14752. At various time points, carbon sources [glucose $(\triangle)$, and/or lactate $(\diamond)$ ] were assayed, and cell wall proteins were recovered from the pellet; the amount of PS2 was quantified (圈) as described in Methods. Biomass (as OD $570, O$ ) is also shown. (a-c) Cells were cultured overnight in MCGC minimal medium supplemented with glucose, then used to inoculate, to an $\mathrm{OD}_{570}$ of $\mathbf{0 . 7}$, minimal medium supplemented with glucose (a), lactate (b) or lactate plus glucose (c). For PS2 determination, the volume of protein extract used was calculated so as to give samples of equivalent optical density at $570 \mathrm{~nm}\left(\mathrm{OD}_{570}=1.05\right)$. ( $\left.\mathrm{d}-\mathrm{f}\right)$ Cells were cultured overnight in MCGC minimal medium supplemented with lactate, then used to inoculate minimal medium supplemented with glucose (d), lactate (e) or lactate plus glucose (f). For PS2 determination, the volume of protein extract used was calculated so as to give samples with equivalent optical density at $570 \mathrm{~nm}\left(\mathrm{OD}_{570}=1 \cdot 25\right)$.

seen on the convex fracture surface (F1) (Chami et al., 1995). C. glutamicum ATCC 14752 cells grown on glucose had only a partial S-layer (Fig. 3a, b), with only small patches detectable. These patches are shown by arrows on convex fracture surfaces F1 (Fig. 3a) and on concave fracture surfaces F2 (Fig. 3b). A similar discontinuous S-layer has been described for C. glutamicum Bl15 (Peyret et al., 1993; Chami et al., 1995). In contrast, if the bacteria were grown on lactate (Fig. 3c, d), most were completely covered by the S-layer. Thus, the overproduction of PS2 protein in cultures grown on lactate $\left[30 \mathrm{mg}(\mathrm{g} \mathrm{dry} \mathrm{wt})^{-1}\right.$ ] resulted in an increase in the area covered by the S-layer. Similar results were obtained with Corynebacterium sp. 2262 (data not shown). Very few S-layer patches were observed in the presence of glucose, and significantly more patches were detected in the presence of lactate. However, Corynebacterium sp. 2262, unlike C. glutamicum ATCC 14752, was not completely covered with ordered arrays in the presence of lactate. The lower extent of the S-layer correlated with the lower amount of PS2 protein associated with the cell wall $\left[15.8 \mathrm{mg}(\mathrm{g} \text { dry wt })^{-1}\right]$ in this strain.

On glucose, C. melassecola ATCC 17965 produced
$31.5 \mathrm{mg}$ PS2 (g dry wt) ${ }^{-1}$ (Fig. 2) and had a complete Slayer [Fig. 4a (convex fracture surface F1) and 4b (concave fracture surface F2)]. In the presence of lactate, PS2 production increased to $98 \mathrm{mg}$ (g dry wt $)^{-1}$ (Fig. 2), and ordered arrays were still present on the cell surface (Fig. 4c). The imprint of the S-layer (see the convex fracture surface) is barely visible, but remarkably, the concave fracture surface F2, is densely covered with non-ordered particles (Fig. 4d). This may result from the accumulation of an excess of PS2 protein under the Slayer.

\section{Effect of alteration of carbon source on PS2 production}

C. glutamicum ATCC 14752 cells were cultured overnight in glucose-containing medium. They were then used to inoculate a medium containing glucose (Fig. 5a), lactate (Fig. 5b) or a mixture of lactate and glucose (Fig. $5 \mathrm{c})$. There was a large increase in PS2 production during the exponential phase of growth in cultures containing lactate as the sole carbon source (Fig. 5b). This suggests that PS2 accumulates in the cell wall after stimulation of its synthesis by lactate consumption. In cultures con- 
Table 1. $\beta$-Galactosidase activity produced under the control of a $\operatorname{csp} B$ promoter in various strains of Corynebacterium grown in MCGC minimal medium

\begin{tabular}{|c|c|c|c|c|}
\hline \multirow[t]{2}{*}{ Bacterial strain } & \multirow[b]{2}{*}{ Carbon source... } & \multicolumn{2}{|c|}{$\beta$-Galactosidase activity* } & \multirow{2}{*}{$\begin{array}{c}\text { Ratio } \\
\text { (lactate/glucose) }\end{array}$} \\
\hline & & Glucose & Lactate & \\
\hline C. glutamicum ATCC 14752 & & ND & ND & - \\
\hline C. glutamicum ATCC 14752(pCGL1504) & & $5 \cdot 31 \pm 0 \cdot 13$ & $12 \cdot 65 \pm 1 \cdot 3$ & $2 \cdot 4$ \\
\hline Corynebacterium sp. 2262 & & ND & ND & - \\
\hline Corynebacterium sp. 2262(pCGL1504) & & $3 \cdot 19 \pm 0 \cdot 42$ & $11 \cdot 24 \pm 1 \cdot 05$ & $3 \cdot 5$ \\
\hline Corynebacterium sp. 2262::pCGL1502 & & $0 \cdot 215 \pm 0 \cdot 025$ & $1.52 \pm 0.09$ & $7 \cdot 1$ \\
\hline
\end{tabular}

ND, Not detected.

*Activity was determined using cells in stationary phase and is expressed as $\left[A_{420} \mathrm{~min}^{-1}\left(\mu \mathrm{g}\right.\right.$ protein) $\left.{ }^{-1}\right] \times 1000$. Values are the means of at least six independent determinations $\pm \mathrm{SE}$.

taining both lactate and glucose (Fig. 5c), an increase in PS2 production was also observed, suggesting that the stimulatory effect of lactate consumption on PS2 synthesis was independent of glucose.

We then cultured C. glutamicum ATCC 14752 cells overnight in lactate-containing medium and used them to inoculate medium containing glucose (Fig. 5d), lactate (Fig. 5e) or a mixture of lactate and glucose (Fig. 5f). There was a large decrease in PS2 production during growth in cultures containing glucose as the sole carbon source (Fig. 5d). Cultures with mixed carbon sources produced the large amounts of PS2 associated with lactate consumption (Fig. 5f). We observed strong stimulation of PS2 production in cultures with lactate as the sole carbon source. The amount of PS2 perg bacterial dry weight steadily increased throughout the exponential phase in lactate cultures from both glucosegrown and lactate-grown inocula, and then decreased in the stationary phase (Fig. $5 \mathrm{~b}$ and $5 \mathrm{e}$ ).

Experiments similar to those performed with $C$. glutamicum ATCC 14752 were then carried out with C. melassecola ATCC 17965 and Corynebacterium sp. 2262. For C. melassecola ATCC 17965, results similar to those observed with C. glutamicum ATCC 14752 were obtained (data not shown). The single carbon source results obtained with Corynebacterium sp. 2262 were similar to those for C. glutamicum ATCC 14752 (data not shown). In cultures with mixed carbon sources, no PS2 was produced in cultures from glucose-grown inocula and there was a decrease in PS2 production in cultures from lactate-grown inocula (results not shown). These observations suggest that the inhibitory effect of glucose consumption was predominant in this strain.

\section{$\operatorname{csp} B$ expression level as a function of carbon source}

We investigated the regulation of PS2 production by constructing an in-phase fusion between the $P \operatorname{csp} B$ promoter and the E. coli lacZ gene. First, pCGL1502 carrying an in-phase fusion between $l a c Z$ and the first codon of $\operatorname{csp} B$ was constructed in E. coli $\mathrm{DH} 5 \alpha \mathrm{F}^{\prime}$ (Fig. 1a). As pCGL1502 cannot replicate in Corynebacterium, its transfer by electroporation may lead to its integration into the chromosome at either the $i c d$ locus or the $\operatorname{csp} B$ locus. We transformed the Corynebacterium sp. 2262 strain with pCGL1502 and selected five kanamycinresistant recombinant strains. The structure of the insertion in these recombinant strains was determined by Southern blotting and a single copy of pCGL1502 was found to have inserted by homologous recombination at the $i c d$ locus in each (data not shown). One recombinant strain, Corynebacterium sp. 2262::pCGL1502, was studied further.

Plasmid pCGL1504 was then constructed, containing the PcspB-lacZ fusion, and able to replicate in Corynebacterium. This plasmid was constructed in E. coli $\mathrm{DH} 5 \alpha \mathrm{F}^{\prime}$ and transferred into E. coli JM110 (Fig. 1b). pCGL1504 was introduced by electroporation into C. glutamicum ATCC 14752 and Corynebacterium sp. 2262, producing the recombinant strains ATCC 14752(pCGL1504) and 2262(pCGL1504) respectively.

$\beta$-Galactosidase activity was measured after culture on MCGC minimal medium containing either glucose or lactate (Table 1 ). Activity was $2 \cdot 4$-fold higher in ATCC 14752(pCGL1504), 3.5-fold higher in 2262(pCGL1504) and $7 \cdot 1$-fold higher in Corynebacterium sp. 2262::pCGL1502 grown in the presence of lactate. These ratios are similar to those observed for PS2 production in lactate and suggested that regulation occurs mainly at the level of protein synthesis.

\section{DISCUSSION}

Using three strains of Corynebacterium, each with a different rate of PS2 production, we found that the amount of S-layer protein depended on the carbon source available in the growth medium. We also found that the area covered by the S-layer closely correlated with the amount of PS2 produced. In C. glutamicum ATCC 14752 and Corynebacterium sp. 2262, which produced only small amounts of PS2 when cultured on glucose $\left[8 \mathrm{mg}(\mathrm{g} \text { dry wt })^{-1}\right.$ and $1.2 \mathrm{mg}(\mathrm{g} \text { dry wt })^{-1}$, respectively], only small patches of S-layer were observed. The cell surface was not completely covered by the S-layer if less than $30 \mathrm{mg}$ PS2 $\left(\mathrm{g}\right.$ dry wt) ${ }^{-1}$ was produced, consistent with the results of Chami et al. 
(1995). The presence of an S-layer partially covering the cell surface suggests that it is a dynamic component of the cell envelope. In conditions in which large amounts of PS2 were produced $\left[98 \mathrm{mg}(\mathrm{g} \text { dry wt })^{-1}\right.$ for C. melassecola ATCC 17965 cultured on lactate], the ordered arrays on the convex fracture surface were barely visible and the concave fracture surface was densely covered with non-ordered particles. These particles may correspond to PS2 protein accumulation under the S-layer, which has already been described in B. stearothermophilus (Breitwieser et al., 1992).

The current lack of knowledge about the function of the S-layer in Corynebacterium makes it difficult to relate its regulation by a carbon source to a particular function. The natural carbon source used by Corynebacterium in its biotope is unknown. It is commonly found in the soil (Trautwetter \& Blanco, 1988) and organic acids may be its principal substrates. The S-layer may therefore be associated with adhesion sites for exoenzymes, surface recognition and cell adhesion to substrates, as has been suggested for the S-layers of several other organisms (Beveridge et al., 1997).

We showed, using a lacZ fusion, that PS2 production was mainly regulated by changes in $c s p B$ gene expression and that secretion was probably not a limiting step in PS2 accumulation at the cell surface. A few examples of the regulation of S-layer formation have been described (Bahl et al., 1997), but regulation by carbon source has not previously been reported. In B. brevis 47 , one of the five promoters of the operon encoding cell wall proteins is specifically active in the exponential phase of growth (Adachi et al., 1989). We observed that growth phase had an effect on PS2 production but the promoter sequences of $\operatorname{csp} B$ involved have not yet been determined. In T. thermophilus HB8 (Fernández-Herrero et al., 1997), there is evidence that $s l r A$ encodes a transcriptional repressor of the S-layer gene. It has been suggested that SlrA is also linked with other metabolic pathways, such as those involved in cell wall synthesis.

We observed co-metabolism of both substrates in all three strains, extending the observation by Cocaign (1992) of simultaneous glucose and lactate consumption in C. melassecola ATCC 17965. The inhibitory effect of glucose consumption on PS2 production was much greater in Corynebacterium sp. 2262 than in the other strains. This suggests that the use of metabolic pathways differs between strains. Glucose catabolism by central pathways in C. melassecola ATCC 17965 has been examined using NMR (Rollin et al., 1995), enzymic (Cocaign-Bousquet et al., 1996) and mathematical modelling (Pons et al., 1996) approaches. These studies have shown that the pentose pathway is responsible for almost $50 \%$ of glucose catabolism in this strain. One of the key aspects of sugar catabolism in C. melassecola is the manner in which an adequate supply of NADPH is generated to meet anabolic requirements. The pentose phosphate pathway, which involves two NADP-dependent dehydrogenases, is the principal source of $\mathrm{NADPH}$ during growth on glucose. The differences in flux distribution for glucose-grown and lactate-grown cells shows clearly that different NADPH-generating reactions operate in lactate-grown cells. During growth on lactate, a modified tricarboxylic acid cycle involving malic enzyme and an unknown enzyme with pyruvate carboxylating activity is thought to operate, accounting for the apparent shortfall of NADPH for anabolic requirements (Cocaign-Bousquet \& Lindley, 1995). Such studies performed to analyse carbon flux in Corynebacterium sp. 2262 support the idea that major differences exist in metabolism of glucose in these two Corynebacterium strains (N. D. Lindley, personal communication).

\section{ACKNOWLEDGEMENTS}

C. de Sousa-D'Auria and E. Soual-Hoebeke made equal contributions to this work. We would like to thank T. GulikKrzywicki, E. Shechter and B. Holland for helpful discussions. We are also grateful to Orsan SA for providing Corynebacterium strains. This work was supported by grants from the Centre National de la Recherche Scientifique (CNRS), Orsan SA and the Université Paris-Sud (France).

\section{REFERENCES}

Adachi, T., Yamagata, H., Tsukagoshi, N. \& Udaka, S. (1989). Multiple and tandemly arranged promoters of the cell wall protein gene operon in Bacillus brevis 47. J Bacteriol 171, 1010-1016.

Adachi, T., Yamagata, H., Tsukagoshi, N. \& Udaka, S. (1991). Repression of the cell wall protein gene operon in Bacillus brevis 47 by magnesium and calcium ions. J Bacteriol 173, 4243-4245.

Aggerbeck, L. P. L. \& Gulik-Krzywicki, T. (1986). Studies of lipoproteins by freeze-fracture and etching electron microscopy. Methods Enzymol 128, 457-472.

Apostolakos, D., Menter, P. A., Rampsch, B. J., Reeves, H. C. \& Birge, E. A. (1982). Genetic map position of the cistron coding for isocitrate dehydrogenase in Escherichia coli K-12. Curr Microbiol 7, 45-47.

Ausubel, F. M., Brent, R., Kingston, R. E., Moore, D. D., Seidman, J. G., Smith, J. A. \& Struhl, K. (1987). Currents Protocols in Molecular Biology. New York: Wiley.

Bahl, H., Scholz, H., Bayan, N. \& 27 other authors (1997). Molecular biology of S-layers. FEMS Microbiol Rev 20, 47-98.

Bayan, N., Schrempp, S., Joliff, G., Leblon, G. \& Shechter, E. (1993). Role of the protonmotive force and of the state of the lipids in in vivo protein secretion in Corynebacterium glutamicum, a gram-positive bacterium. Biochim Biophys Acta 1146, 97-105.

Beveridge, T. J., Pouwels, P. H., Sára, M. \& 22 other authors (1997). Functions of S-layers. FEMS Microbiol Rev 20, 99-149.

Birnboim, H. C. \& Doly, J. (1979). A rapid alkaline extraction procedure for screening recombinant plasmid DNA. Nucleic Acids Res 7, 1513-1523.

Bonamy, C., Guyonvarch, A., Reyes, O., David, F. \& Leblon, G. (1990). Interspecies electro-transformation in Corynebacteria. FEMS Microbiol Lett 54, 263-269.

Boot, H. J. \& Pouwels, P. H. (1996) Expression, secretion and antigenic variation of bacterial S-layer proteins. Mol Microbiol 21, 1117-1123.

Boot, H. J., Kolen, C. P. A. M., Andreaki, F. J., Leer, R. J. \& Pouwels, P. H. (1996a). The Lactobacillus acidophilus S-layer protein gene expression site comprises two consensus promoter 
sequences, one of which directs transcription of stable mRNA. J Bacteriol 178, 5388-5394.

Boot, H. J., Kolen, C. P. A. M. \& Pouwels, P. H. (1996b). Interchange of the active and silent S-protein genes of Lactobacillus acidophilus by inversion of the chromosomal slp segment. Mol Microbiol 21, 799-809.

Breitwieser, A., Gruber, K. \& Sleytr, U. B. (1992). Evidence for an S-layer protein pool in the peptidoglycan of Bacillus stearothermophilus. J Bacteriol 174, 8008-8015.

Casadaban, M. J., Chou, J. \& Cohen, S. N. (1980). In vitro gene fusions that join an enzymatically active $\beta$-galactosidase segment to amino-terminal fragments of exogenous proteins: Escherichia coli plasmid vectors for the detection and cloning of translational initiation signals. J Bacteriol 143, 971-980.

Chami, M., Bayan, N., Dedieu, J. C., Leblon, G., Shechter, E. \& Gulik-Krzywicki, T. (1995). Organization of the outer layers of the cell envelope of Corynebacterium glutamicum: a combined freeze-etch electronmicroscopy and biochemical study. Biol Cell 83, 219-229.

Chu, S., Gustafson, C. E., Feutrier, J., Cavaignac, S. \& Trust, T. J. (1993). Transcriptional analysis of the Aeromonas salmonicida Slayer protein gene vapA. J Bacteriol 175, 7968-7975.

Cocaign, M. (1992). Croissance de Corynebacterium glutamicum sur divers substrats et répartition des flux dans les voies $d u$ métabolisme central. PhD thesis, Institut National des Sciences Appliquées de Toulouse.

Cocaign-Bousquet, M. \& Lindley, N. D. (1995). Pyruvate overflow and carbon flux within the central metabolic pathways of Corynebacterium glutamicum during growth on lactate. Enzyme Microb Technol 17, 260-267.

Cocaign-Bousquet, M., Guyonvarch, A. \& Lindley, N. D. (1996). Growth rate dependent modulation of carbon flux through central metabolism and the kinetic consequences for glucoselimited chemostat cultures of Corynebacterium glutamicum. Appl Environ Microbiol 62, 429-436.

Debay, F. (1997). Etude cinétique de la fermentation glutamique par C. glutamicum et caractérisation physiologique par cytométrie en flux. PhD thesis, Institut National Polytechnique de Lorraine.

Dwokin, J. \& Blaser, M. J. (1996). Generation of Campylobacter fetus S-layer protein diversity utilizes a single promoter on an inversible DNA segment. Mol Microbiol 19, 1241-1253.

Eikmanns, B. J., Rittman, D. \& Sahm, H. (1995). Cloning, sequence analysis, expression, and inactivation of the Corynebacterium glutamicum icd gene encoding isocitrate dehydrogenase and biochemical characterization of the enzyme. J Bacteriol 177, 774-782.

Fernández-Herrero, L. A., Olabarría, G. \& Berenguer, J. (1997). Surface proteins and a novel transcription factor regulate the expression of the S-layer gene in Thermus thermophilus HB8. Mol Microbiol 24, 61-72.

Fisher, J. A., Smit, J. \& Agabian, N. (1988). Transcriptional analysis of the major surface array gene of Caulobacter crescentus. J Bacteriol 170, 4706-4713.

Garcia, M. M., Lutze-Wallace, C. L., Denes, A. S., Eaglesome, M. D., Holst, E. \& Blaser, M. J. (1995). Protein shift and antigenic variation in the S-layer of Campylobacter fetus subsp. venerealis during bovine infection accompanied by genomic rearrangment of sapA homologs. J Bacteriol 177, 1976-1980.

Gulik-Krzywicki, T. \& Costello, M. J. (1978). The use of low temperature X-ray diffraction to evaluate freezing methods used in freeze-fracture electron microscopy. J Microsc 112, 103-113.
Joliff, G., Mathieu, L., Hahn, V., Bayan, N., Duchiron, F., Renaud, M., Shechter, E. \& Leblon, G. (1992). Cloning and nucleotide sequence of the $\operatorname{csp} 1$ gene encoding PS1, one of the two major secreted proteins of Corynebacterium glutamicum: the deduced $\mathrm{N}$-terminal region of PS1 is similar to the Mycobacterium antigen 85 complex. Mol Microbiol 6, 2349-2362.

Kahala, M., Savoijoki, K. \& Palva, A. (1997). In vivo expression of Lactobacillus brevis S-layer gene. J Bacteriol 179, 284-286.

Labarre, J., Reyes, O., Guyonvarch, A. \& Leblon, G. (1993). Gene replacement, integration, and amplification at the $g d h \mathrm{~A}$ locus of Corynebacterium glutamicum. J Bacteriol 175, 1001-1007.

Laemmli, U. K. (1970). Cleavage of structural proteins during the assembly of the head of bacteriophage T4. Nature 227, 680-685.

Lewis, L. O., Yousten, A. A. \& Murray, R. G. E. (1987). Characterization of the surface protein layers of the mosquito-pathogenic strains of Bacillus sphaericus. J Bacteriol 169, 72-79.

Liebl, W. \& Sinskey, A. J. (1988). Molecular cloning and nucleotide sequence of a gene involved in the production of extracellular DNase by Corynebacterium glutamicum. In Genetics and Biotechnology of Bacilli, pp. 383-388. Edited by A. T. Ganesan \& J. A. Hoch. New York: Academic Press.

Messner, P. \& Sleytr, U. B. (1992). Crystalline bacterial cellsurface layers. Adv Microbiol Physiol 33, 213-275.

Mondain-Monval, F. (1988). Cinétiques, modélisation et développement d'estimateurs de la fermentation glutamique. $\mathrm{PhD}$ thesis, Institut National Polytechnique de Lorraine.

Olabarría, G., Carrascosa, J. L., De Pedro, M. A. \& Berenguer, J. (1996). slpM, a gene coding for an 'S-layer-like array' overexpressed in S-layer mutants of Thermus thermophilus HB8. J Bacteriol 178, 357-365.

Peyret, J. L., Bayan, N., Joliff, G., Gulik-Krzywicki, T., Mathieu, L., Shechter, E. \& Leblon, G. (1993). Characterization of the $\operatorname{csp} B$ gene encoding PS2, an ordered surface-layer protein in Corynebacterium glutamicum. Mol Microbiol 9, 97-109.

Pons, A., Dussap, C. G., Pequignot, C. \& Gros, J. B. (1996). Metabolic flux distribution in Corynebacterium melassecola ATCC17965 for various carbon sources. Biotechnol Bioeng 51, 177-189.

Reyes, O., Guyonvarch, A., Bonamy, C., Salti, V., David, F. \& Leblon, G. (1991). 'Integron'-bearing vectors: a method suitable for stable chromosomal integration in highly restrictive corynebacteria. Gene 107, 61-68.

Rollin, C., Morgant, V., Guyonvarch, A. \& Guerquin-Kern, J. L. (1995). ${ }^{13} \mathrm{C}-\mathrm{NMR}$ studies of Corynebacterium melassecola metabolic pathways. Eur J Biochem 227, 488-493.

Sára, M. \& Sleytr, U. B. (1994). Comparative studies of S-layer proteins from Bacillus stearothermophilus strains expressed during growth in continuous culture under oxygen-limited and non-oxygen-limited conditions. J Bacteriol 176, 7182-7189.

Sára, M., Kuen, B., Mayer, H. F., Mandl, F., Schuster, K. C. \& Sleytr, U. B. (1996). Dynamics in oxygen-induced changes in S-layer protein synthesis from Bacillus stearothermophilus PV72 and the S-layer-deficient variant T5 in continuous culture and studies of the cell wall composition. J Bacteriol 178, 2108-2117.

Sleytr, U. B. \& Glauert, A. M. (1976). Ultrastructure of the cell walls of two closely related clostridia that possess different regular arrays of surface subunits. J Bacteriol 126, 869-882.

Sleytr, U. B. \& Messner, P. (1989). Self-assembly of bacterial cell surface layers (S-layers). In Electron Microscopy of Subcellular Dynamics, pp. 13-31. Edited by H. Plattner. Boca Raton, FL: CRC Press.

Sleytr, U. B., Messner, P., Pum, D. \& Sára, M. (1996). Occurrence, 
location, ultrastructure and morphogenesis of S-layers. In Crystalline Bacterial Cell Surface Proteins, pp. 5-33. Edited by U. B. Sleytr, P. Messner, D. Pum \& M. Sára. Austin, TX:: R. G. Landes/Academic Press.

Trautwetter, A. \& Blanco, C. (1988). Isolation and preliminary characterization of twenty bacteriophages infecting either Brevibacterium or Arthrobacter strains. Appl Environ Microbiol 54, 1466-1471.

Trieu-Cuot, P. \& Courvalin, P. (1983). Nucleotide sequence of the Streptococcus faecalis plasmid gene encoding the $3^{\prime} 5^{\prime \prime}$ aminoglycoside phosphotransferase type III. Gene 23, 331-341.
Von der Osten, C. H., Gioannetti, C. \& Sinskey, A. J. (1989). Design of a defined medium for growth of Corynebacterium glutamicum in which citrate facilitates iron uptake. Biotechnol Lett 11, 11-16.

Yanisch-Perron, C., Vieira, J. \& Messing, J. (1985). Improved M13 phage cloning vectors and host strains: nucleotide sequences of the M13mp18 and pUC19 vectors. Gene 33, 103-119.

Received 7 May 1999; revised 13 September 1999; accepted 15 September 1999. 